10

\title{
Nuclear Borders: Informally Negotiating the Chernobyl Exclusion Zone
}

Thom Davies

\section{Introduction}

... so I was at the checkpoint where they check the cars for everything that is prohibited from leaving the Zone, and I was caught by one of the guards. He said 'What is that in your bag?' And I said 'Mush- rooms', and the guard said 'You know that mushrooms are especially prohibited from leaving the zone?' And I said 'Yes I know, but they are not for me!' [laughter] And the militia asked 'Well who are they for?' and I said 'They are for my mother in law' [laughter] And the militia said 'OK, have a nice trip!'

Viktor, late forties, former Chernobyl liquidator

Borders have been a part of Viktor's life for most of his adulthood. Until the 'anthropological shock' (Beck, 1987) of the 1986 Chernobyl nuclear disaster, Viktor was doing national service as a border guard on the western edge of the Soviet Union. He showed me photographs of his former self: uniformed, proud and young. They were stuck carefully into a velvet-clad scrap book of a previous life. He patrolled the barbed wire fence that separated the USSR from the Socialist Republic of Romania, miles away from his home near a power station in northern Ukraine, where we now sat: 'After Chernobyl it all changed' he said. He shows me a pile of 'liquidator' passes which he held until 2008, each one signed and stamped with a nuclear warning symbol next to a photograph of his face. A different, more serious man stared back, his face the embodiment of life on the margins. These passes let him enter the $30 \mathrm{~km}$ 'Zone of Alienation' which surrounds the exploded reactor, and contains some of To cite: Davies T. (2015) 'Nuclear Borders: Informally Negotiating the Chernobyl Exclusion Zone' in Morris J \& Polese A. [eds] Informal Economies in Post-Socialist Spaces: Practices, 
the highest levels of nuclear contamination on earth. A contamination that is a constant threat, but remains completely invisible.

The ubiquitous yet invisible presence of informal activity also dwells within the 'floating mists' (Lefebvre, 2000: 98; Round et al., 2008: 172) of post-socialist space, not threatening the marginalized but helping them negotiate everyday life. Beyond the more obvious street-level traders, most informal activity - for good reason - occurs beyond the state's 'panoptic gaze' (Foucault, 1977). The seemingly invisible nature of this economy is suggested in the various names it is given: from 'shadow' to 'underground' to 'hidden' or 'black', there is an under- lying assumption that informal activity takes place in 'other worlds' (Gibson-Graham, 2008: 1). Of course, not all formal economic activ- ity is visible - from secret board meetings to the everyday action of covering your PIN code - but it is the enigma of the informal that both perplexes and continues to attract a growing intellectual inter- est. This scholarly fascination stretches back to academics such as Keith Hart (1973) through to structuralist (Fortuna and Prates, 1989; Wallerstein, 2007) and more recent post-structuralist interpretations (Gibson-Graham, 2006; Latouche, 1993; Smith and Stenning, 2006). Yet, despite a growing interest in informal economies, the majority of academic discourse still maintains that market forces have penetrated almost every sphere of modern society (Williams et al., 2011), and the complex role that informality plays in people's lives remains under-researched.

In Ukraine, the route through post-socialism is no longer planned by neoliberal ideas of 'transition' from A to B, or mapped out by a super- imposed Washington-consensus cartography; in fact, there is no 'route' at all (Buraway, 2002; Ledneva, 2004; Stenning, 2005). Instead, cop- ing mechanisms such as economies of favours (Kuehnast and Dudwick, 2004; Pavlovskaya, 2004; Polese, 2008), informal/undeclared work (Stenning, 2005; Williams and Round, 2007, 2010), 'social acknowledge- ment' (Morris, 2011: 629), gift exchange (Mauss, 2002), social capital (Moran, 2001; Round, 2006), blat (Onoshchenko and Williams, 2013), social networks (Grabher and Stark, 1997; Lonkila, 1997, 1999; Walker, 2010) and memory (Buyandelgeriyn, 2008), have all helped circumvent the challenges of post-Soviet everyday life.

Previous scholarship that has focused on the monetary nature of informality has been challenged by recent research that highlights the complete entanglement of the informal sphere into the social fabric of society (Bourdieu, 2001; Gibson-Graham, 1996, 2006; Lee, 2006; Zelizer, 2005). For example, scholars have emphasized how informality often

To cite: Davies T. (2015) 'Nuclear Borders: Informally Negotiating the Chernobyl Exclusion Zone' in Morris J \& Polese A. [eds] Informal Economies in Post-Socialist Spaces: Practices, 
occurs within kin networks, friendship groups and family units (Nelson and Smith, 1999; Smith and Stenning, 2006; Williams and Round, 2008), and is often so socially embedded as to hold cultural and social significance that extends beyond mere economic rationales (Parry and Block, 1989). Such is the prevalence of these behaviours that one can argue that informality has become the rule and formality is the exception (Routh, 2011). This case study starts from this basis to highlight not only how informal activity around the Chernobyl Exclusion Zone helps people survive day-to-day abandonment, but also how these informal activities help reinforce social relations and understandings of complex and risky environments.

\section{An ethnography of Chernobyl}

This chapter is based on over three years of ethnographic research around the Chernobyl border region in Ukraine, on territory officially contaminated by the 1986 nuclear accident. Ethnographic methods were employed, including over 100 semistructured and informal interviews with local residents, border guards, gatekeepers, evacuees, returnees, liquidators and community leaders. Local elites such as mayors were also interviewed, but in a more formal setting and style. Other key research tools included the extensive use of participant observation and a visual methodology, which involved participant photography research, discussed more extensively elsewhere (Davies, 2013). As with other research in post-socialist space (Harrowell 2014; Disney 2015), the identities of all participants are concealed and any information that may be damaging to those I have spent time with has been withheld.

The ongoing Chernobyl disaster has recently become the focus of scholarship in social science and humanities fields such as human geography (Davies, 2013, 2015; RushCooper, 2013), sociology (Kuchinskaya, 2010, 2013, 2014; Morris-Suzuki 2014), history (Marples, 2004; Kalmbach, 2013; Geist 2015; Schmid 2015), area studies (Davies and Polese, 2015) and anthropology (Petryna, 2002, 2011; Phillips, 2005; Phillips and Ostaszewski, 2012; Arndt, 2012), as well as visual studies (Bürkner, 2014), literature studies (Gerstenberger 2014) and tourism (Stone, 2013; Yankovska and Hannam, 2014). These researchers share the realization that the Chernobyl accident has diverse understandings and multiple realities, with disputed impacts that extend well beyond its official nuclear geography and its enigmatic death toll. For some, the nuclear disaster has come to exemplify the failure of state socialism - not only in the way the disaster itself contributed to the

To cite: Davies T. (2015) 'Nuclear Borders: Informally Negotiating the Chernobyl Exclusion Zone' in Morris J \& Polese A. [eds] Informal Economies in Post-Socialist Spaces: Practices, 
sudden disintegration of the USSR (van der Veen, 2013), but also in the way that the Exclusion Zone today has become a symbolic space for a bygone Soviet age, where tourists flock to gaze upon the frozen 'other' of communism and reproduce their own 'ruin porn' (Davies, 2013, 2015).

In the years following the disaster, over 350,000 people were dis- placed as 'ecological refugees' (Brown, 2011: 32), and the number of deaths remains a highly contentious issue.1 But what these numbers fail to expose is the huge sociological, economic and psychological effect that Chernobyl had, and continues to have, for many thou- sands of people in Ukraine and beyond. Adriana Petryna posits that after Chernobyl, 'scientific knowability collapsed' (2004: 250) and a new 'informal economy of diagnoses and entitlement' was created (ibid.: 263). In a post-Chernobyl world where harmful radiation is invisible to the lay perspective, informal methods of overcoming this technological blindness emerged. Doctors were bribed not only for better healthcare, but to diagnose a more lucrative Chernobyl disability status (Petryna, 2002). Sites of healthcare, such as hospitals, are well-known spaces of informal exchange (Mæstad and Mwisongo, 2011; Morris and Polese, 2014; Polese, 2006, 2008), but Chernobyl presented a scenario where an individual's entire bio-political status could be altered through bribery and connections. New forms of 'biocitizenship' (Petryna, 2002) surfaced after Chernobyl whereby a higher disability status equalled more social benefits. Suddenly, an individual's damaged biology became useful bio- capital to be informally traded within the state's healthcare system. Individuals who had been (out)cast as post-nuclear 'bare life' (Agamben, 1998) after Chernobyl could now informally renegotiate their vulnerable economic and social position in this fledgling capitalist economy. This research expands upon these findings, to explore how informal activity has permeated the everyday lives of those who dwell in the shadow of the Chernobyl disaster.

\section{Theorizing Chernobyl}

Chernobyl exemplifies a 'state of exception' (Agamben, 2005) - a space where the normal rules of governance, state protection, and citizenship do not apply. Here - as in other modern spaces of exception suggested by Giorgio Agamben, such as Guantanamo Bay or Nazi concentration camps - certain people are excluded from the normal protections of the law. With Chernobyl, the emplacement of nuclear 'Exclusion Zones' and governance from Ukraine's 'Ministry of Emergencies' ensures that a permanent state of exception persists. As such, those living in

To cite: Davies T. (2015) 'Nuclear Borders: Informally Negotiating the Chernobyl Exclusion Zone' in Morris J \& Polese A. [eds] Informal Economies in Post-Socialist Spaces: Practices, 
Chernobyl-affected spaces can be viewed as 'homo sacer' (Agamben, 1998) - their individual biologies no longer the responsibility of the state. To live inside contaminated territory is, therefore, to live outside the protection of the law. As such, Chernobyl can be considered a perfect case study for ethnography at the margins of society. It is here that the tension between the citizen and the state is more visible (Polese, 2011). I argue that informality - in terms of not only informal economic practice but also informal understandings of nuclear space - is a key way in which individuals are able to enact agency and circumvent their status of post-nuclear bare life.

This informality takes place against a backdrop of state violence and neglect. Recent scholarship argues that the failure to adequately compensate and protect citizens can be framed as a form of violence (Gilbert and Ponder, 2014; Li, 2009), especially in situations of forced displacement (Shaw, 2013). This is not the physical violence of genocide or 'thanatopolitics' (Foucault, 2003: 230), but, rather, a 'stealthy violence' (Li, 2009: 67) of abandonment that casts Chernobyl citizens outside the de facto protection of the state, and forces them to rely on informal actions and understandings of their nuclear landscape. It is within this context of abandonment that Chernobyl-affected citizens are compelled to employ unofficial understandings of space, and enact informal activities which circumvent their bio-political status of bare life, as illustrated by the following ethnographic vignettes.

\section{A tapestry of informality}

Through his window, a flat expanse of uncultivated land spreads to the horizon - a bank of conifer trees dividing the summer sky from the steppe. Beyond the trees is the Exclusion Zone. Looking around the bed- room of his home, Viktor explains how 'every piece of wood in this house is from the Zone'. He described how there is plenty of material in the Zone that can be salvaged if you know the right people; if you have the right connections. Numerous abandoned homes and collective farms lie beyond the distant conifer trees. Explaining how he could smuggle people past the checkpoints, he even offered: 'I have an old friend who works for the militia, maybe I could get us into the Zone?' Where Viktor's social networks could not be used to negotiate this nuclear border, he described other informal methods:

I would buy six bottles of vodka and beer in Chernobyl, and then I would take it to the second border to bribe [the militia]. And then

To cite: Davies T. (2015) 'Nuclear Borders: Informally Negotiating the Chernobyl Exclusion Zone' in Morris J \& Polese A. [eds] Informal Economies in Post-Socialist Spaces: Practices, 
they asked for 5 litres of petrol. So I took this from the car and then we entered the inner zone.

This mixture of social network and 'gift-giving' to negotiate the various levels of border control shows how informal activity is a normalized part of everyday life. Each of the three checkpoints within the Zone - the outer $30 \mathrm{~km}$ perimeter, the $10 \mathrm{~km}$ inner checkpoint and the final guard post around the 'ghost city' of Pripyat near the reactor required altering styles of informal subversion. This ranged from paying the border guards to giving them gifts to simply being friends with them: a tapestry of informality as sophisticated as it was normalized. But this also had an affective dimension: Viktor's descriptions of his encounters with the Zone were full of emotion - with obvious pride that he knew how to subvert the official nuclear borders.

While recounting his various exploits within the Zone, his expression was that of the young soldier in his military scrapbook, and unlike the aged portraits shown on his liquidator pass. He had a clear sense of satisfaction in beating the system. A border such as the one seen through Viktor's window, between the 'clean' and 'contaminated' territory of north-central Ukraine, is a 'place where it is possible to see the potential conflict between the citizens and their state amplified to the maximum' (Polese, 2011: 22). For Viktor, being able to negotiate the state-enforced border was a minor victory against a government that had done so little to help him. As de Certeau suggests, for those who lack power, there is a 'pleasure in getting around the rules of a constraining space' (de Certeau, 1984: 18).

Many people affected by Chernobyl feel that they have been 'exposed' twice - once to the hidden threat of radiation, and once more to a state that has abandoned them (Davies, 2013). Viktor's mild pleasure in being able to informally subvert the 'border processes' (Newman, 2006) that occur within sight of his own house was tangible: part 'resistive', but at the same time an embedded social practice. 'It's our tradition', he explained. Informal economic activity is vital for Viktor and his wife to supplement their small formal income. In 2008, he was sacked from his job as a driver in Chernobyl after an argument with his boss about not being paid for half a month's work. His wife Masha, now the main bread- winner, works two jobs, getting paid around $£ 150$ per month. Their combined income gives them just enough to get by. On top of this, 'the government give us 2 Hryvnia and 10 kopeks a month to buy clean food',2 explains Masha, 'What the hell can we get with that?' Many informants complained about the low level of Chernobyl compensation that they receive. This paltry amount, which 
originates from the early

1990s and does not increase with inflation, reinforces the reality that people are living on contaminated territory, yet does nothing in the way of actually helping. 'We couldn't even buy bread with that', said Viktor. Most of the food that Masha and Viktor eat is grown themselves, in the very soil against which the compensation is supposed to mitigate. Their son visits them most weekends from his job in Kyiv, often taking fresh produce back to the city, connecting this nuclear landscape with the rest of Ukraine.

\section{Food for thought}

As in other rural spheres of post-socialist space, self-provisioning is an important survival strategy in this bucolic, if contaminated, landscape. Viktor explained how he intended to exchange surplus sacks of potatoes with members of his local social network: 'I have no money to pay them, only potatoes. If I have the money to pay them then I do.' The potatoes were stored below a wooden outbuilding where he and Masha keep a few farm animals; a milking cow and three pigs, their chickens roaming around the yard. The smallholding was typical of the parcels of land found in the Chernobyl border region, more 'household plot' (Czegledy, 2002: 203) than farm. Between formal employment and looking after their elderly relatives who live nearby, there is little time for growing surplus cash crops. In the small, cool cellar, above the mounds of potatoes grown earlier in the summer, an array of other self-cultivated or foraged foods stood high on shelves, pickled in large jars: onions, tomatoes, mushrooms, beetroot, berries, gherkins and a variety of other fruit and vegetables sealed in glass. Though a prosaic scene to anyone familiar with post-Soviet rural life, it is one made distinct and remarkable by the contention that the consumption of radiation in food 'for those living near Chernobyl - is practically unavoidable' (Phillips, 2005: 288). Yet this array of hardearned produce in Masha and Viktor's cellar was, for them at least, untarnished by the threat of radiation. If the jars represented anything, it was not the invisible threat from contamination, but the months of toil it had taken to put the food there in the first place; domestic food production in Ukraine should not be over-romanticized (Round et al., 2010). Like other forms of informality, the self-cultivated and gathered food was an expression of agency - minor victories against the uncertainty of poverty: each jar an 'economic cushion' (Czegledy, 2002, 209) that exists beyond the formal economy.

Large-scale post-socialist marginalization has meant that many Ukrainians are forced to prioritize the basic struggle for food security rather than worry about the food's 'ecological state (ekolohichnyi stan)'

To cite: Davies T. (2015) 'Nuclear Borders: Informally Negotiating the Chernobyl Exclusion Zone' in Morris J \& Polese A. [eds] Informal Economies in Post-Socialist Spaces: Practices, 
(Phillips, 2005: 288). As one elderly woman who lives near the edge of the Exclusion Zone explained, in the confusion and chaos after Chernobyl, she was told to avoid eating various foodstuffs such as berries and mushrooms, or drinking locally produced milk, but:

if you are not going to drink or eat everything that they say, then you won't even have the energy to move even your legs . . . you'll have no power to even move your legs...

Viktor took the potatoes to his friend, who was sitting in a boat moored at the water's edge very near the border of the Chernobyl Exclusion Zone. Concealed from the road, between a smallholding and the tall reeds that are synonymous with the Pripyat Marshes, around 30 men were busily folding fishing nets, repairing their boats and hauling in the morning's catch. The number and size of the fish suggested that this was not just evidence of 'the growing commercialization of rural house- hold production' (Pallot and Nefedova, 2003: 47) but part of a wider industry of informal (and formal) activity that takes place in this bor- der region. Dilapidated concrete signs nearby read 'Fishing is Strictly Forbidden', as the river here runs past the 'most contaminated water body in the zone of the Chernobyl accident' (Kryshev, 1995: 217). The unfixed and ephemeral character of this watercourse that flows through the Exclusion Zone itself adds one more layer of liminality to an already fuzzy nuclear border. While it was not possible to trace the end des- tination of these prohibited fish via a 'follow the thing' (Cook, 2004) approach, respondents suggested that the fish were destined to be sold for money in cities such as Kyiv, as opposed to being solely exchanged within localized kin networks - the sheer amount of fish collected in large nets made this monetary outcome inevitable. Environmentally risky foodstuffs from restricted areas, such as mushrooms, game, berries and fish, regularly enter the food chain in Ukraine through various informal actions involving trespassing over the official borders of the Exclusion Zone (Davies, 2011). A curious consequence of imposing an 'Exclusion Zone' the size of Greater London has been the resulting boom in wildlife, including fish stocks.

\section{The informal pull of place}

'All of the men you saw are criminals, you see - it is illegal to fish there. And they are dangerous...' said Viktor that evening over a bowl of soup made from the traded fish, 'but I am not afraid of them'. Nor

To cite: Davies T. (2015) 'Nuclear Borders: Informally Negotiating the Chernobyl Exclusion Zone' in Morris J \& Polese A. [eds] Informal Economies in Post-Socialist Spaces: Practices, 
was he afraid of the higher levels of radiation that could be found in the food. Viktor is a well-connected man, his large social network vital to his household survival strategies: allowing him to weave in between the informal and formal; to tactically access spaces that have been sub- divided, forbidden and controlled by those with power (de Certeau, 1984). When asked whether he was ever tempted to move away from this region to somewhere less contaminated, he explained that it would be worse for his health to emigrate from the landscape he knows best:

Most of the people who left here died very quickly, because they had not been accepted into their surroundings... when they left separately, away from people they knew, they died from stress.

This is a widespread opinion held by those living in this region: that it is better to live with the invisible threat of radiation than to risk the tangible reality of severing social networks, and thus harming the ability to use informal methods of survival and reciprocity. This was not based on an opinion that Chernobyl radiation is risk free; indeed, every respondent had personal experiences of death and tragedy associated with the accident; but, rather, on an understanding that moving away would shatter social networks and the ability to sustain themselves through informal means.

The significance placed on the agency of informal activity - even in this extreme environment - speaks to the importance of informal- ity throughout Ukraine in general, and, indeed, many other spheres of post-socialist space. Even on the edge of the Chernobyl Exclusion Zone, where radiological risk makes some informal activity hazardous, the ability to act informally is given a very high importance by local inhabitants. The capacity to use social networks, informal activity and local knowledge to survive outside the formal economy is placed above the risk of contamination. This has parallels with previous research in extremely marginalized areas of the former Soviet Union, such as Magadan in Russia's Far East. Here, individuals who face extreme economic and climatic conditions reject relocation to more affluent areas due to the threat of damaging their informal survival techniques and social networks, on which they so completely depend (Round, 2006).

To an outsider, the nuclear borderland around Chernobyl is the antithesis of a 'therapeutic landscape' (Gesler and Kearns, 2002: 132) or 'therapeutic space' (McCormack, 2003: 490). However, to marginalized individuals who are able to negotiate everyday life through subverting the border processes of the Zone, or through social networks and

To cite: Davies T. (2015) 'Nuclear Borders: Informally Negotiating the Chernobyl Exclusion Zone' in Morris J \& Polese A. [eds] Informal Economies in Post-Socialist Spaces: Practices, 
informal economic activity, the risk from radiation is less of a threat than the reality of migrating elsewhere. Many people who were given the theoretical opportunity to be resettled to less contaminated territory decided not to leave, citing the reasons that connect them to their landscape: that they would not know anyone if they were resettled, that their loved ones are buried here, that those who left have 'died from stress'. This nuclear landscape may be polluted, but it is still home. The risk of not being able to perform informal activity is framed as a greater risk than the ever-present threat of radiation. The agency demonstrated through expertise in the local area and the mobility of knowing where to informally cross into the Exclusion Zone, for example, is paired with the wider significance of immobility: of wanting to remain living with the known landscape, however polluted it may be. The reliance on local knowledge of the landscape and social networks creates an informal pull of place that goes beyond formal techno-scientific understandings of place and radiation risk. When analysing why individuals stay within environmentally dangerous environments such as Chernobyl, their ability to perform informal activity that subverts the official understandings of space should not be underestimated. A key example of such informal activity is the prosaic, yet illegal and potentially harmful, act of gathering food inside the Exclusion Zone.

\section{Nuclear mushrooms}

For economically marginalized individuals living on the border of Chernobyl's nuclear Exclusion Zone, illegal mushroom and berry foraging in contaminated areas is a widespread informal activity. Often, this food is sold in urban centres in Ukraine. The ebb and flow of these goods is an unseen but prosaic example of an informal economic activity that has potential health implications. These wild foods are some of the most harmful in a nuclear landscape because of the high levels of radiation that they can contain. Indeed, levels of contamination in individuals increases dramatically during the foraging season (Botsch et al., 2001). This fact is combined with the social and anthropological importance of foraged foods, especially in post-socialist space, relating to identity, spirituality and survival (Caldwell, 2007; Staddon, 2009; Stryamets et al., 2012; Yasmin-Pasternak, 2009). Despite mushroom and berry collection being banned in contaminated regions, especially inside the Zone itself, this informal behaviour is a widespread and normalized part of every- day life for marginalized individuals in this border region. With the use of foraged products 'ranging from emergency food for the hungry to

To cite: Davies T. (2015) 'Nuclear Borders: Informally Negotiating the Chernobyl Exclusion Zone' in Morris J \& Polese A. [eds] Informal Economies in Post-Socialist Spaces: Practices, 
the mark of the festive table' (Yasmin-Pasternak, 2008: 95), it is per- haps unsurprising that many people collect, consume and sell berries and mushrooms that are potentially 'unclean'. This paradox of invisibly tainted, yet abundant nature was summed up concisely by a woman who lives on the edge of the Zone: 'The nature here is really beautiful ... ' said Svetlana (late 50s), 'it's just that people from the USSR fucked it up.' Svetlana, who lives a few hundred metres from the fence around the Chernobyl Exclusion Zone, was at her local cemetery during Easter provody celebrations, where people traditionally visit the graves of their relatives and eat and drink to their memory. Svetlana had brought home-made vodka and mushrooms with her, but was alone that day, as her husband was at home due to illness and her son, who is a guard in the Exclusion Zone, had to be at work. As a priest walked past repeating a prayer and sprinkling holy water, she explained where the mushrooms were from. Like many people, she had taken them from within the Exclusion Zone itself - the forbidden forests of the Zone are only a short walk from her front door. She explained how she knew which areas were clean and which were harmful, insisting that beyond the fence 'into the zone for some kilometres it is clean'. Although Svetlana does not own any scientific equipment able to 'see' the radiation, she insists that she knows which areas are 'dirty'. Her informal activities in the zone are intrinsically linked to her informal understanding of radiation risk.

When asked whether she was worried that she would get into trouble with the police if she was found inside the Exclusion Zone, she described how most of the border guards just turn a blind eye to 'an old lady like me'. Many of the militia are part of Svetlana's social network:

The border guards come to my house sometimes and they say 'Baba Svetlana, please make us some food' and so I do ... I am very friendly with them.

Other respondents described how border militia often stop in for a cup of coffee in their homes as they make their rounds patrolling the border. She described, too, how during high season a van from Kyiv arrives in her border village to buy foraged mushrooms and berries that people have collected. The van then goes to Kyiv, where the food is sold on informally. For example, that season, after Svetlana had preserved enough berries and jam for her own household, she sold $37 \mathrm{~kg}$ of surplus berries to these men, making around $f 50$. Considering that her formal household income from her husband's and her own pension comes to $£ 125$ per month, this extra money proves very useful. Other people

from

To cite: Davies T. (2015) 'Nuclear Borders: Informally Negotiating the Chernobyl Exclusion Zone' in Morris J \& Polese A. [eds] Informal Economies in Post-Socialist Spaces: Practices, Institutions and Networks London: Palgrave Macmillan (225-244) 
the border region sell mushrooms at the side of the road leading to the cities of Ivankiv and Kyiv. While this is a very important and everyday informal activity in post-socialist space, it is made exceptional because of the invisible threat of radiation. This informal activity around the nuclear border should not be viewed in terms of an 'arbitrage opportunity' (Cassidy, 2011: 634), one based in pure economic terms, with goods being cheaper on one side of the border than the other (ibid.; Bruns and Migglebrink, 2012), but, rather, based on local understandings of radiation risk relating to a privileged 'sense of place': an opinion that lay knowledge is more reliable than state-supported ideas of 'clean' and 'dirty'. As Svetlana explained when talking about collecting food from inside the Exclusion Zone,

Many people ask me 'are you not afraid of radiation?' and I tell them 'What can I do? It hasn't got any smell...and it is invisible... what can I do?' There is not even any clicking...

There are few more alternative foods than those taken from con-taminated rivers and soils within (and without) Chernobyl's official landscape, to be exchanged through gift, barter and social networks and to arrive at street level at the top of metro staircases in the bustling heart of urban Kyiv; or, more visibly, to be eaten by local inhabitants of the Chernobyl border region, not in a 'grow-your-own' act of romanticized post-socialist defiance, or in denial that radiation is a very real and harmful reality, but simply to survive. For marginalized house- holds on the edge of this nuclear landscape, the collection of food from within the Exclusion Zone is just one aspect of the formal and informal behaviours that construct their survival strategies. Indeed, the potential risk from radiation is only one of a number of threats that punctuate everyday life, including the risk of getting caught performing the illegal activity, not to mention the enduring and highly visible - risk of poverty.

\section{The fence}

That winter, the flat expanse of uncultivated land seen through Viktor's window was white with snow, the distant conifer trees drooping under its weight. Viktor and his brother-in-law Igor (late 60s) walked through the trees until they came to the border fence: the physical embodiment of a failed state attempt to contain harmful radiation. Everything beyond the border was illegal space, a post-nuclear space of exception

To cite: Davies T. (2015) 'Nuclear Borders: Informally Negotiating the Chernobyl Exclusion Zone' in Morris J \& Polese A. [eds] Informal Economies in Post-Socialist Spaces: Practices, 
where different rules, modes of behaviour and exclusions apply. It is, of course, like any other fence: six feet high, with concrete posts every few metres, and topped with barbed wire. Low-level radiation is not stopped by it, nor are the informal ebbs and flows of people and goods from within the Zone - as indicated by the large person-sized hole in front of which Viktor and Igor were standing. Of course, as with many borders, 'the state is the ultimate judge and has the right to set limits, to decide what is good and what is bad' (Polese, 2011: 22): what is inside and outside, what is 'clean' or 'unclean'. It is the state that decides on the official boundaries, nuclear borders, and limitations of an invisible risk, that emplaces and performs the official nuclear geographies of the Exclusion Zone. On the other side of the fence a track runs parallel to the border, allowing the militia to patrol, and beyond that is the dark- ness of more woodland. Standing in front of one of the many holes in this porous border, Viktor explained how

The militia sometimes wait in the forest and then wait for you to cross the border, then they catch you. It depends who caught you, you may be able to bribe.

Igor described how he used to remove scrap metal from the Zone, taking it from the many abandoned buildings on the other side of the fence. He described selling the metal 'to different dealers. We take it to the fac- tory where it is crushed, melted down, and mixed with other metals ...' From here it is in the formal economic sphere, and 'it is impossible to find or trace it' - it becomes invisible. The informal removal of scrap metal, though not as common as mushroom picking, was described by several respondents as a key informal economic activity. In a landscape of widespread unemployment, the money one can make is relatively high. However, the risk of getting caught performing this illegal activity is a real possibility. For example, Igor had an ongoing deal with the border guards that meant he could drive a vehicle in and out of the Zone unchecked. However,

We took scrap metal out of the Zone, with a lorry - I took my brother but he is not so generous. You see, we had an agreement with the militia that meant we could take scrap out through an unofficial route... so when we left the Zone on the way back they arrested us. The price of the agreement was three litres of vodka. But when we were arrested there was no longer any chance of giving a bribe. This was a year and a half ago. They took us out of the lorry, surrounded us

To cite: Davies T. (2015) 'Nuclear Borders: Informally Negotiating the Chernobyl Exclusion Zone' in Morris J \& Polese A. [eds] Informal Economies in Post-Socialist Spaces: Practices, 
with guns and put our face in the sand, and beat us. After that, they took us to a judge in Ivankhiv and we had to pay a 150 hryvnia fine.

That could have been avoided if his brother had provided the vodka. The official punishment was a fine of 150 hryvnia ( $£ 12$ ) each; the unofficial punishment (for not providing the vodka) was a beating from the militia and the end of future informal links with these border police. When asked how much he could make from a successful journey out of the Zone, he explained how each loaded lorry can fetch 2,500 hryvnia ( $£ 200)$, which is then split between two or three men.

Viktor described how during the hunting season he would shoot four or five animals and sell their furs: 'I have a constant buyer of the furs. I also get money for the meat as well as the furs.' This informal activity more than doubled his formal income from his liquidator pension. Igor, too, was a hunter, preferring to set traps within the Zone, describ- ing how he goes 'through the deepest parts of the forest that the militia never enter - they are afraid'. He was not sure whether that year would be so profitable, worrying that the government 'will be securing this area for the 25th anniversary'. Sure enough, during the anniversary in April 2011 the Exclusion Zone became a postChernobyl 'Potemkin Village' for the world's media. Medvedev, Yanukovich and Ban KiMoon all posed in front of the reactor - soon to be refurbished at a cost of hundreds of millions of pounds. Thirty kilometres away, standing on the edge of the Zone (and society), things are different: 'we have no way out - unless you can you steal something; if you cannot steal something - you are hungry....' said Igor, staring through the hole in this permeable nuclear border.

\section{Conclusion}

As discussed earlier, Chernobyl can be viewed as a state of exception: an extreme situation that is governed in a way that recasts the affected citizens as 'bare life' (Agamben, 1998, 2005), abandoning them to their own devices. Informal activity can be seen as a way of subverting this state of exception, a way of claiming back agency. The fence, a physical expression of this state of exception, is as porous to radiation as it is to the to-and-fro of informal activity. Indeed, Viktor spoke with great pride of his home he had built almost entirely from Chernobyl-sourced material, by subverting the official rules of the nuclear landscape.

To cite: Davies T. (2015) 'Nuclear Borders: Informally Negotiating the Chernobyl Exclusion Zone' in Morris J \& Polese A. [eds] Informal Economies in Post-Socialist Spaces: Practices, 
Unlike other informal activities around borders, what makes this case study unique is the added concern of health. Each example of informal enterprise described above from trading home-grown potatoes for illegally caught fish, to picking mushrooms within the Exclusion Zone, or even trying to smuggle out contaminated scrap metal has potential, though invisible, health implications. Just as there are informal and formal economic activities, so, too, are there informal understandings of health and radiation risk. The example of bribing doctors to provide a more financially lucrative Chernobyl disability status further complicates this confluence between informal activity and health (Petryna, 2002). So does the oft-mentioned accusation made by research participants that some people had illegally acquired liquidator passes in order to claim compensation, thus informally entering the formal protection of Chernobyl's sprawling if massively underfunded - welfare system. Just as individuals who live near the Exclusion Zone are able to navigate the boundary between nuclear and non-nuclear space, so, too, are some people throughout Ukraine able to informally subvert the 'nuclear borders' of the social welfare system - through informal payments or bribes and connections.

The same in-depth local knowledge that allows Igor to navigate the Zone undetected while hunting also allows him, and others such as Svetlana, the confidence to decide which areas are contaminated and which are clean. The formal geography of Chernobyl has been created and emplaced by the state, but how these spaces are interpreted by individuals in everyday life is open to informal negotiation.

Informal activity can be used as a means to circumvent the stealthy violence of abandonment; a tactical method of asserting agency over spaces from which you have been excluded. In the same way that the lay perspective cannot see the invisible 'blinding light' (Petryna, 2002: 75) of Chernobyl's harmful radiation, so, too, do those who govern this nuclear state of exception fail to see informal economic activities even when state actors such as border guards are implicated. From the removal of scrap metal from the Exclusion Zone itself, to more prosaic activities such as foraging and selling food sourced from within and without the Zone, informal behaviours are entwined into the everyday fabric of life on the edge. Through these embedded informal behaviours, we can also get a better appreciation of what it is like living under the spectre of nuclear radiation, in spaces where the official nuclear narratives are not the only ways of understanding space.

To cite: Davies T. (2015) 'Nuclear Borders: Informally Negotiating the Chernobyl Exclusion Zone' in Morris J \& Polese A. [eds] Informal Economies in Post-Socialist Spaces: Practices, 


\section{Notes}

1. Justifiable estimates of Chernobyl-related deaths range from 4,000 (IAEA, 2011) to a figure well in excess of one million (Yablokov et al., 2009).

2. This monthly compensation is only 10 pence at the time of writing.

\section{References}

Agamben, G. (1998) Homo Sacer: Sovereign Power and Bare Life, California: Stanford University Press.

Agamben, G. (2005) State of Exception, London: The University of Chicago Press. Arndt, M. (2012) Memories, commemorations, and representations of Chernobyl: Introduction, Anthropology of East Europe Review, 30(1), 1-12.

Beck, U. (1987) The anthropological shock: Chernobyl and the contours of the risk society, Berkeley Journal of Sociology, 32, 153-165.

Botsch, W., L.D. Romantschuk, D. Beltz, J. Handl and R. Michel (2001) Investigation of the radiation exposure of inhabitants of contaminated areas in northern Ukraine, Centre for Radiation Protection and Radiocology, 1-8. Bourdieu, P. (2001) The forms of capital, in Biggart, W.N. (ed.) Readings in Economic Sociology, Oxford: Blackwell, 141-163.

Brown, L. (2011) World on the edge: How to prevent environmental and economic collapse, London: W.W. Norton \& Co Publishers.

Bruns, B. and J. Migglebrink (2012) Subverting Borders: Doing Research on Smuggling and Small Scale Trade, Germany: VS Verlag für Sozialwissenschafte.

Buraway, M. (2002) Transition without transformation: Russia's involuntary road to capitalism, in Nugent, D. (ed.) Locating Capitalism in Time and Space: Global Restructurings, Politics and Identity, London: Stanford University Press, 290-310.

Bürkner, D. (2014) The Chernobyl Landscape and the Aesthetics of Invisibility, Photography and Culture, 7(1), 21-39.

Buyandelgeriyn, M. (2008) Post-post-transition theories: Walking on multiple paths, Annual Review of Anthropology, 37, 235-250.

Caldwell, M. (2007) Feeding the body and nourishing the soul: Natural food in post-socialist Russia, Food Culture and Society: An International Journal of Multidisciplinary Research, 10(1), 43-71.

Cassidy, K. (2011) Performing the cross border economies of post-socialism, International

To cite: Davies T. (2015) 'Nuclear Borders: Informally Negotiating the Chernobyl Exclusion Zone' in Morris J \& Polese A. [eds] Informal Economies in Post-Socialist Spaces: Practices, 
Journal of Sociology and Social Policy, 21(11), 612-618.

Cook, I. (2004) Follow the thing: Papya, Antipode, 36(4), 642-664.

Czegledy, A. (2002) Urban peasants in a post-socialist world: Small-scale agricul- turalists in Hungary, in Leonard, P. and Kaneff, D. (eds.) Post-Socialist Peasant? Rural and Urban Constructions of Identity in Eastern Europe, East-Asia and the Former Soviet Union, New York: Palgrave, 200-221.

Davies, T. (2011) Nuclear mushrooms: Attitudes to risk and the state through food consumption in the Chernobyl border region, in Universitas 21 Graduate Research on Food Proceedings, Nottingham University, Malaysia Campus, June, 92-96.

Davies, T. (2013) A visual geography of Chernobyl: Double exposure, International Labor and Working-Class History, 84, 116-139.

Davies, T. (2015) Half Lives and Bare Life: An Informal Geography of Chernobyl, PhD thesis, University of Birmingham, UK.

Davies, T. and A. Polese (2015) Informality and survival in Ukraine's nuclear land- scape: Living with the risks of Chernobyl, Journal of Eurasian Studies, 6 (1), 34-45.

de Certeau, M. (1984) The Practice of Everyday Life, London: University of California Press.

Disney, T (2015) Complex spaces of orphan care-a Russian therapeutic children's community, Children's Geographies, 13(1), 30-43.

Fortuna, J.C. and S. Prates (1989) Informal sector versus informalized labor rela- tions in Uruguay, in Portes, A., Castells, M. and Benton, L.A. (eds.) The Informal Economy: Studies in Advanced and Less Developed Countries, Baltimore: Johns Hopkins University Press, 78-94.

Foucault, M. (1977) Discipline and Punish: The Birth of the Prison, New York: Pantheon Books.

Foucault, M. (2003) Society Must Be Defended: Lectures at the Collége de France, 1975-1976, New York: Picador.

Geist, E. (2015) Political Fallout: The Failure of Emergency Management at Chernobyl, Slavic Review, 74(1), 104-126.

Gerstenberger, K. (2014) Störfälle: Literary Accounts from Chernobyl to Fukushima, German Studies Review, 37(1), 131-148.

Gesler, W. and R. Kearns (2002) Culture, Place and Health, London: Routledge.

Gibson-Graham, J.K. (1996) The End of Capitalism (As We Knew It): A Fem-inist Critique Of Political Economy, Minneapolis: University of Minnesota Press.

Gibson-Graham, J.K. (2006) A Post-Capitalist Politics, Minneapolis: University of Minnesota

To cite: Davies T. (2015) 'Nuclear Borders: Informally Negotiating the Chernobyl Exclusion Zone' in Morris J \& Polese A. [eds] Informal Economies in Post-Socialist Spaces: Practices, 
Press.

Gibson-Graham, J.K. (2008) Diverse economies: Performative practices for 'otherworlds', Progress in Human Geography, 32(5), 1-20.

Gilbert, E. and C. Ponder (2014) Between tragedy and farce: 9/11 compensation and the value of life and death, Antipode, 46 (2), 404-425.

Grabher, G. and D. Stark (1997) Restructuring Networks in Post-Socialism Legacies, Linkages and Localities, London: Clarendon Press.

Harrowell, E. (2014) From monuments to mahallas: contrasting memories in the urban landscape of Osh, Kyrgyzstan, Social \& Cultural Geography, 16(2) 203-225.

Hart, K. (1973) Informal income opportunities and urban employment in Ghana, The Journal of Modern African Studies, 11(1), 61-89.

IAEA (2011) Statement to International Conference on Chernobyl: Twenty-Five Years On - Safety for the Future, Kyiv: International Atomic Energy Agency.

Kalmbach, K. (2013) Radiation and borders: Chernobyl as a national and transnational site of memory, Global Environment, 11, 130-159.

Kryshev, I. (1995) Radioactive contamination of aquatic ecosystems following the Chernobyl accident, Journal of Environmental Radioactivity, 27(3), 207-219.

Kuchinskaya, O. (2010) Articulating the signs of danger: lay experiences of post-Chernobyl radiation risk and effects, Public understandings of Science, 1, 1-17.

Kuchinskaya, O. (2013) Twice invisible: Formal representations of radiation danger, Social Studies of Science 43 (1) 78-96. Kuchinskaya, O. (2014) The Politics of Invisibility: Public Knowledge about Radiation Health Effects After Chernobyl, Massachusetts: MIT Press.

Kuehnast, K. and N. Dudwick (2004) Better a Hundred Friends than a Hundred Rubles? Social Networks in Transition - the Kyrgyz Republic, Washington, DC: World Bank working paper.

Latouche, S. (1993) In the Wake of Affluent Society: An Exploration of Post Development, London: Zed Publications.

Ledneva, A. (2004) Ambiguity of Social Networks in Post-Communist Contexts, Working Paper No. 48. School of Slovanic and East European Studies, UCL.

Lee, R. (2006) The ordinary economy: Tangled up in values and geography, Transactions of the Institute of British Geographers, 31(4), 413-432.

Lefebvre, H. (2000) Everyday Life in the Modern World, London: Athlone. Li, T. (2009) To make live or let die? Rural dispossession and the protection of surplus populations, Antipode, 41, 6693.

To cite: Davies T. (2015) 'Nuclear Borders: Informally Negotiating the Chernobyl Exclusion Zone' in Morris J \& Polese A. [eds] Informal Economies in Post-Socialist Spaces: Practices, 
Lonkila, A. (1997) Informal exchange relations in post-soviet Russia: A comparative perspective, Sociological Research Online, 2(2).http://socresonline.org.uk/2/2/9.html.

Lonkila, M. (1999) Social Networks in Post-Soviet Russia: Continuity and Change in the Everyday Life of St Petersburg Teachers, Helsinki: Kikimora Publications.

Mæstad, O. and A. Mwisongo (2011) Informal payments and the quality of healthcare: Mechanisms revealed by Tanzanian health workers, Health Policy, 99(2), 107-115.

Marples, D. (2004) Chernobyl: A Reassessment, Eurasian Geography and Economics, 45 (8), 588-607.

Mauss, M. (2002) The Gift: The Form and Reason for Exchange in Archaic Societies, London: Routledge.

McCormack, D. (2003) An event of geographical ethics in spaces of affect, Transactions of the Institute of British Geographers, 28(4), 488-507.

Moran, D. (2001) Forestry villages in the Russian north - social capital and subsistence at the margins, Belgian Journal of Geography, 3, 199-213.

Morris, J. (2011) Socially embedded workers at the nexus of diverse work in Russia: An ethnography of blue-collar work informalization, International Journal of Sociology and Social Policy, 3(11), 619-631.

Morris, J. and A. Polese (2014) Informal health and education sector payments in Russian and Ukrainian cities: Structuring welfare from below, European Urban and Regional Studies, 1-16.

Morris-Suzuki, T. (2014) Touching the Grass: Science, Uncertainty and Everyday Life from Chernobyl to Fukushima, Science Technology \& Society, 19(3), 331-362.

Nelson, M.K. and J. Smith (1999) Working Hard and Making Do: Surviving in Small Town America, Berkeley, CA: University of California Press.

Newman, D. (2006) The lines that continue to separate us: Borders in our 'borderless' world, Progress in Human Geography, 30(2), 143-161.

Onoshchenko, O. and C.C. Williams (2013) Paying for favours: Evaluating the role of blat in postSoviet Ukraine, Debatte: Journal of Contemporary Central and Eastern Europe, 21, 2-3, 259277.

Pallot, J. and T. Nefedova (2003) Geographical differentiation in household plot production in rural Russia, Eurasian Geography and Economics, 44(1), 40-64.

Parry, J.P and M. Block (1989) Money and the Morality of Exchange, Cambridge: Cambridge University Press.

Pavlovskaya, M. (2004) Other transitions: Multiple economies of Moscow house-holds in the

To cite: Davies T. (2015) 'Nuclear Borders: Informally Negotiating the Chernobyl Exclusion Zone' in Morris J \& Polese A. [eds] Informal Economies in Post-Socialist Spaces: Practices, 
1990s, Annals of the Association of American Geographers, 94(2), 329-351.

Petryna, A. (2002) Life Exposed: Biological Citizens after Chernobyl, Oxford: Princeton University Press.

Petryna, A. (2004) Biological citizenship: The science and politics of Chernobyl- exposed populations, Osiris, 19(1), 250-265.

Petryna, A. (2011) Chernobyl's survivors: Paralyzed by fatalism or overlooked by science. Bulletin of the Atomic Scientists, 67(2), 30-37.

Phillips, S. (2005) Half-lives and healthy bodies: Discourses on 'contaminated' food and healing in post-Chernobyl Ukraine, in Watson, J. and Caldwell, M. (eds.) The Cultural Politics of Food and Eating, Oxford: Blackwell Publishing, 286-298.

Phillips, S. and S. Ostaszewski (2012) An illustrated guide to the post-catastrophe future, Anthropology of East Europe Review, 30(1), 127-140.

Polese, A. (2006) Border crossing as a daily strategy of post Soviet survival: The Odessa-Chisinau Elektrichka, Eastern European Anthropology Review, 24(1), 28-37.

Polese, A. (2008) 'If I receive it, it is a gift: If I demand it, then it is a bribe': On the local meaning of economic transactions in post-Soviet Ukraine', Anthropology in Action, 15(3), 47-60.

Polese, A. (2011) Who has the right to forbid and who to trade? Making sense of illegality on the Polish-Ukrainian border, in Bruns, B. and Migglebrink, J. (eds.) Subverting Borders: Doing Research on Smuggling and Small Scale Trade, Germany: VS Verlag für Sozialwissenschafte, 2138.

Round, J. (2006) Marginalized for a lifetime: The everyday experiences of gulag survivors in postSoviet Magadan, Geografiska Annaler: Series B, Human Geography, 88(1), 15-34.

Round, J., C.C. Williams and P. Rodgers (2008) Everyday tactics and spaces of power: The role of informal economies in post-Soviet Ukraine, Social \& Cultural Geography, 9(2), 171-185.

Round, J., C. Williams and P. Rodgers (2010) The role of domestic food production in everyday life in post-Soviet Ukraine, Annals of the Association of American Geographers, 100(5), 11971211.

Routh, S. (2011) Building informal workers agenda: Imagining 'informal employ- ment' in conceptual resolution of 'informality', Global Labour Journal, 2(3), 208-227.

Rush-Cooper, N. (2013) Exposures: Exploring Selves and Landscapes in the Chernobyl Exclusion Zone, PhD thesis, Durham University, UK.

Schmid, S. D. (2015) Producing Power: The Pre-Chernobyl History of the Soviet Nuclear Industry, Massachusetts: MIT Press.

To cite: Davies T. (2015) 'Nuclear Borders: Informally Negotiating the Chernobyl Exclusion Zone' in Morris J \& Polese A. [eds] Informal Economies in Post-Socialist Spaces: Practices, 
Shaw, M. (2013) What is Genocide?, London: John Wiley \& Sons. Smith, A. and A. Stenning (2006) Beyond household economies: Articulations and spaces of economic practice in postsocialism, Progress in Human Geography, 30(1), 1-14.

Staddon, C. (2009) Toward a critical political ecology of human-forest interactions: Collecting herbs and mushrooms in a Bulgarian locality, Transactions of the Institute of British Geographers, 34(1), 161-176.

Stenning, A. (2005) Post-socialism and the changing geographies of the everyday in Poland, Transactions of the Institute of British Geographers, 30(1), 113-127.

Stone, P. (2013) Dark tourism, heterotopias and post-apocalyptic places: The case of Chernobyl, in White, L. and E. Frew (Eds.), Dark tourism and place identity, Melbourne: Routledge, Melbourne, 79-93.

Stryamets, N., M. Elbakidze and P. Angelstam (2012) Role of non-wood for- est products for local livelihood in countries with transition and market economies: Case studies in Ukraine and Sweden, Scandinavian Journal of Forest Research, 27(1), 74-87.

Van der Veen, M. (2013) After Fukushima: Revisiting Chernobyl and the Collapse of the Soviet Union, Rethinking Marxism, 25(1), 121-129.

Walker, C. (2010) Space, kinship networks and youth transition in Provin- cial Russia: Negotiating urban-rural and inter-regional migration, Europe-Asia Studies, 62(4), 647-669.

Wallerstein, I. (2007) World-systems Analysis, Durham: Duke University Press. Williams, C. and J. Round (2007) Re-thinking the nature of the informal econ- omy: Some lessons from Ukraine, International Journal of Urban and Regional Research, 31(2), 425-441.

Williams, C.C. and J. Round (2008) The hidden enterprise culture of Moscow: Entrepreneurship and off-the-books working practices, Journal of Developmental Entrepreneurship, 13(04), 445462.

Williams, C.C. and J. Round (2010) Explaining participation in undeclared work: A result of exit or exclusion? European Societies, 12(3), 391-418.

Williams, C., S. Nadin, P. Rodgers, J. Round and J. Windebank (2011) Mapping the social organization of labour in Moscow: Beyond the formal/informal labour dualism, Sociological Research Online, 16(1), 13.

Yablokov, A., V. Nesterenko and A. Nesterenko (2009) Chernobyl: Consequences of the Catastrophe for People and the Environment, New York: Blackwell Publishers.

Yankovska, G. and K. Hannam (2014) Dark and toxic tourism in the Chernobyl exclusion zone, Current Issues in Tourism, 17(10), 929-939.

Yasmin-Pasternak, S. (2008) A means of survival, a marker of feasts: Mushrooms in the Russian Far East, Ethnology, 47(2), 95-107. Zelizer, V.A. (2005) The Purchase of Intimacy, Princeton.

To cite: Davies T. (2015) 'Nuclear Borders: Informally Negotiating the Chernobyl Exclusion Zone' in Morris J \& Polese A. [eds] Informal Economies in Post-Socialist Spaces: Practices, 